\title{
DEFICIENCY WITHIN THE EXTRINSIC PROTHROMBIN ACTIVATOR SYSTEM IN PATIENTS WITH ACUTE SPINAL CORD INJURY
}

\author{
By H. J. Hachen, ${ }^{1}$ A. B. Rossier, ${ }^{2}$ C. A. Bouvier ${ }^{3}$ and J. Ritschard ${ }^{4}$ \\ 1 Spinal Cord Injury Centre from the Institute for Physical Medicine and Rehabilitation, \\ Geneva, Switzerland. \\ 2 Spinal Cord Injury Service from the Veterans Administration Hospital, \\ West Roxbury, Mass. 02132, USA. \\ 3, ${ }^{4}$ Laboratoire d'Hémostase, Haematologic Division, University Hospital, \\ Geneva, Switzerland.
}

LIVER metabolic functions and endocrine activity are known to be affected by spinal cord injury to various degrees (O'Connell et al., 1953). Several authors (Lloyd et al., 1964) have reported on negative nitrogen balance with surprisingly low albumin fractions and depressed adrenal functions, especially in the acute post-traumatic stage. Impaired liver functions may be noticed at the same time (Cooper et al., I950) while endocrine disorders resulting in gynecomastia, testicular atrophy, decreased metabolic rate and low urinary output of steroids are findings that are usually related to a chronic stage beginning five to six months after the lesion. No satisfactory physio-pathological explanation has as yet been offered that correlates level and type of lesion with intensity and pattern of metabolic disturbances. Similar difficulties also arise when one attempts to dissociate possibly direct effects of spinal cord lesion from disorders secondary to non-specific trauma and immobilization.

Frequent findings of subnormal levels of vitamin-K dependent plasma factors II, VII and X, both in acute para- and tetraplegics, retained our interest and motivated the present investigation. Much of our actual knowledge concerning the effect of vitamin $\mathrm{K}$ upon the above-mentioned plasma factors has been derived from animal experimentation (Martius, 1967). In fact, there exist no practical and reliable methods for direct assessment of this vitamin in man. Information on its endogenous synthesis, assimilation, tissue accumulation and excretion is therefore still fragmentary.

Evidence has accumulated indicating considerable variation in the response of healthy individuals to oral or parenteral vitamin $\mathrm{K}$ (Zieve et al., 1969). These variations may be attributed to several factors such as modifications in receptor site affinity within the hepatic tissue or fluctuations in the rate of synthesis and release of vitamin $\mathrm{K}$ dependent clotting factors. Recent investigations (Frick et al., 1967) indicate that minimal daily requirements of vitamin $\mathrm{K}_{1}$ for normal prothrombin complex activity hardly exceed $0.03 \mu \mathrm{g} . / \mathrm{kg}$. It is also known that in the absence of endogenous bacterial synthesis there exist sufficient tissue reserves of vitamin $\mathrm{K}$ to assure normal synthesis of dependent clotting factors for at least three to four weeks (Frick et al., I967).

Individual variation in sensitivity towards vitamin $\mathrm{K}$ has been reported by several hematologists (Quick, 1963) in patients previously well controlled on fixed daily doses of coumarin derivatives and who subsequently received a vitamin $\mathrm{K}$ 
enriched diet. Some evidenced rapid and striking reversal of the anticoagulant effect while others showed only moderate antagonism with partial correction of the clotting factors after the same length of time. Coagulation studies in normal volunteers have shown that hepatic synthesis of clotting factors begins already within six hours af ter the oral administration of 2.5 to $5 \mathrm{mg}$ of vitamin K. However, there exist considerable differences in the rate of synthesis from one person to another (Douglas, 1962).

These introductory remarks concerning normal healthy subjects should be borne in mind before we discuss some of the factors which are possibly responsible for hypoprothrombinemic states in para- and tetraplegics with recent injury to the cord.

\section{CLINICAL RECORDS}

Routine screening tests comprising Quick's one-stage prothrombin time (Rapaport et al., I960) were carried out in 94 patients recently admitted to the Paraplegic Centre of Geneva State Hospital.

Moderate to severe deficiency within the extrinsic prothrombin activator system was found in $6 \mathrm{I}$ cases $(82 \cdot 2$ per cent). As evidenced by further analysis, this deficiency was essentially related to subnormal levels of vitamin $\mathrm{K}$ dependent clotting factors VII and X; factor V, which may be regarded as an indicator of normal hepato-cellular function (Rapaport et al., I960; Satake, I963), was slightly affected in five cases only $(5 \cdot 3$ per cent).

All patients have been analysed with regard to their sex, age, level and type of lesion as well as lapse of time between the spinal cord injury and laboratory assessment of prothrombin activity. After eliminating I4 cases with a former history of slight hepatic dysfunction or intestinal disorders and another group of 42 patients, receiving medication possibly interfering with coumarine-like anticoagulants, we retained 26 para- and 12 tetraplegics for our investigation. Their average age at the onset of the study was $33 \frac{1}{2}$ years (Table).

Among the 26 paraplegics, seven had complete flaccid lesions, I I complete and eight incomplete spastic lesions. Among the 12 tetraplegics, nine had complete and three incomplete spastic lesions. Considering the relatively small number of cases that remained after initial pre-screening, neither the level nor type of lesion can be safely related to the coagulation defect. The same also applies to the time interval between the onset of the lesion and the discovery of abnormally low prothrombin complex activity. In $3 \mathrm{I}$ cases factor VII and X deficiency was evidenced within the first month after injury while the patients were either still in a state of spinal shock or just recovering some reflex activity. In the remaining seven cases the clotting defect became apparent between the fourth and sixth week after the lesion. The physiopathological mechanism responsible for the above-mentioned modifications of the clotting mechanism appears to be of a rather complex nature since it affects both spastic and flaccid, complete and incomplete cases with traumatic spinal cord injury.

Occasionally similar observations can be made in the chronic state, i.e. more than six months after the lesion. However, on statistical grounds these findings are not significant. 
TABLE-Coagulation studies

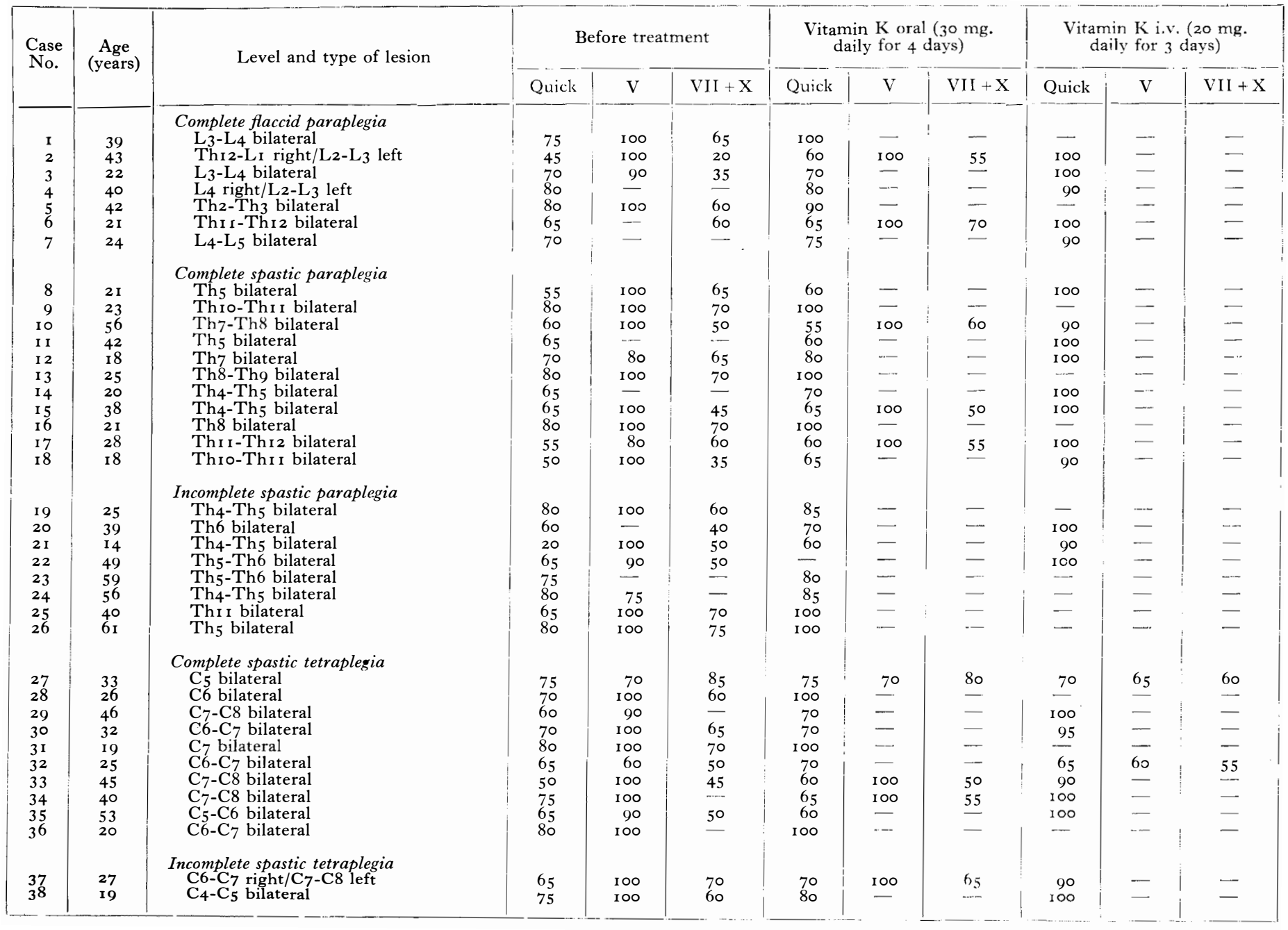




\section{METHODS OF INVESTIGATION AND RESULTS}

The following tests have been carried out on all patients with spontaneous subnormal levels of prothrombin complex activity: complete hemogram; liver function tests; electrophoresis of plasma proteins; thrombelastogram; Quick's one-stage prothrombin time (Quick, I963); Bachmann's method (Bachmann et al., I957) for combined dosage of factors VII and X; Dacie-Lewis (Dacie et al., I963) test for assessment of factor V; complete analysis of the feces.

Correction of factor VII and X deficiency was first attempted by oral administration of high doses of Konakion, a water-soluble, synthetic preparation of vitamin $\mathrm{K}$. The patients received $30 \mathrm{mg}$. per day on four consecutive days. Reevaluation of the clotting factors 24 hours after the last dose showed total correction in nine ( 25 per cent), partial improvement in two ( 5.5 per cent) and no effect in $25(69.5$ per cent) of the cases. Considering the possibility of deficient intestinal resorption, we thereupon treated all 25 refractory cases intravenously with $20 \mathrm{mg}$. of Konakion per day on three consecutive days. Normalisation of factors VII and X was subsequently observed in 23 cases; two patients only showed no response to intravenous vitamin $\mathrm{K}$. In order to avoid possible drug interactions, no other medication was given throughout the trial. No particular restrictions were made concerning the patient's diet. Besides a fairly regular tendency towards moderate hypoalbuminemia and hyper-alpha-I-globulinemia, all other parameters, such as liver function tests, TEG-curves and chemical and microscopic analysis of the stools, gave invariably normal results.

\section{DISCUSSION}

Quick's one-stage prothrombin time expresses the combined activity of factors V, VII and X. Among these, factor VII and X have many physical and chemical properties in common: they both are present in normal serum, stable at room temperature, destroyed at $56^{\circ} \mathrm{C}$, adsorbed by aluminium hydroxide and barium sulphate and dependent upon the presence of vitamin $\mathrm{K}$. Their differentiation is, however, possible through their different coagulation properties. Thus, factor VII is not required for intrinsic thromboplastin formation while factor $\mathrm{X}$ is essential. From a practical point of view, such differentiation has hardly more than an academic interest, all factors tending to decrease together in acquired deficiency states. Isolated marked deficiency of either one factor is rare and usually genetically determined.

Subnormal levels of vitamin $\mathrm{K}$ dependent factors may be encountered in various situations such as during the neonatal period, in cases with hepatic insufficiency (Butt et al., 1938; Warner et al., 1938) or intestinal malabsorption (Moore et al., 1956) and evidently during treatment with coumarin-indanedione anticoagulants. The effects of oral anticoagulants may, as it is well known, be potentiated by a large number of substances: oral administration of large-spectrum antibiotics is likely to alter the intestinal flora and to prevent sufficient endogenous synthesis of vitamin $\mathrm{K}$; other drugs, such as prophylthiouracyl, phenylbutazone and salicylic acid prevent its normal action within the hepatocyte probably through their competitive combination with the apoenzyme.

Little is as yet known about the potentiating effect of clofibrate, a hypolipemic agent, and about the anabolic steroids which also have been shown to influence 
the plasma levels of factors VII and X. Chronic infection and hyperpyrexia may lower the prothrombin complex because of higher requirements and a more rapid turn-over of the vitamin (Wilson et al., I940). Vitamin $\mathrm{K}$ being a liposoluble substance, its intestinal absorption may be interf ered with in the event of steatorrhea or prolonged diarrhoea. In spinal cord injury patients, regular absorption of paraffin oil during bowel training may interfere with normal intestinal uptake of vitamin $\mathrm{K}$, the latter remaining bound to the mineral oil. Occasionally patients on prolonged parenteral feeding show signs of vitamin $\mathrm{K}$ deficiency which may gradually worsen due to concomitant insufficient endogenous synthesis (Berthoud et al., I966).

In our final group of 36 patients all these aetiological factors have very carefully been ruled out. Since normalisation of prothrombin complex activity could be achieved either by very high oral or low intravenous doses of vitamin $\mathrm{K}$ in all but one of our cases, there presumably exists an intestinal barrier for the resorption of lipo-soluble material. Clinical and laboratory investigations with tritiumlabelled vitamin $\mathrm{K}$ would allow for a more refined analysis of the exact mechanism underlying factor VII and X deficiency in acute spinal cord injury.

\section{SUMMARY}

Routine laboratory investigations carried out in 94 cases with acute spinal cord injury indicated moderate to severe deficiency within the extrinsic prothrombin activator system in 82.2 per cent of the patients. The clotting defect could be shown to be related to subnormal levels of vitamin $\mathrm{K}$ dependent plasma factors VII and X. There were 25 drop-outs in this study due to drug interference, irregular administration of vitamin $\mathrm{K}$, intercurrent disease, etc. In the remaining group of 36 patients, none of the common etiological factors of acquired hypoprothrombinemia could be incriminated-such as poor intestinal resorption due to lack of bile salts, hepato-biliary disease, broad-spectrum oral antibiotherapy, drug interaction, hyperpyrexia, prolonged parenteral feeding, etc. In nine ( 25 per cent) of the cases total correction of factors VII and X was achieved af ter oral administration of vitamin $\mathrm{K}$; in two ( 5.5 per cent) partial correction was similarly attained; in the remaining group of $25(69.5$ per cent) who proved to be resistant to oral vitamin $\mathrm{K}$ all but two normalised their factors after intravenous administration of the vitamin. These observations support the hypothesis that in acute spinal cord injury intestinal uptake of lipo-soluble substances may temporarily be impaired.

\section{RÉSUMÉ}

Les examens de laboratoire de routine effectués chez 94 patients atteints d'une lésion médullaire aiguë ont révélé l'existence d'une déficience modérée à sévère du système extrinsèque de l'activation prothrombinique dans $82,2 \%$ des cas. Il s'est avéré que ce défaut de la coagulation était lié à un taux particulièrement bas de facteurs vitamino-Kdépendants VII et X. 25 patients ont dû être éliminés de cette étude à cause d'une interaction médicamenteuse, d'une administration irrégulière de la vitamine $\mathrm{K}$ ou d'une maladie intercurrente. Dans le groupe restant, comportant 36 patients, aucun des facteurs étiologiques habituels d'une hypoprothrombinémie acquise n'a pu être retenu, - tel qu'une mauvaise résorption intestinale due à un manque de sels biliaires, une affection hépatobiliaire, l'antibiothérapie à large spectre par voie orale, une éventuelle interaction médicamenteuse, une alimentation par perfusion i.v. pendant un long laps de temps, etc. Dans neuf cas $(25 \%)$, l'administration orale de vitamine $\mathrm{K}$ a permis d'obtenir une correction totale des facteurs VII et X; dans deux autres cas $(5,5 \%)$, une correction partielle a pu être 
enregistrée. Parmi les 25 patients, $(69,5 \%)$ restés réfractaires au traitement oral tous, sauf deux, ont entièrement corrigé leurs facteurs après l'administration intraveineuse de la vitamine. Ces observations appuient l'hypothèse salon laquelle la résorption intestinale de substances liposolubles serait temporairement inhibée en cas de lésion médullaire aiguë.

\section{ZUSAMMENFASSUNG}

In routinemässig durchgeführten Laboruntersuchungen an 94 Patienten mit akuter Querschnittslähmung wurde in $82,2 \%$ der Fälle eine mittelschwere bis starke Störung des externen Prothrombinaktivator-systems festgestellt. Der betreffende Koagulationdefekt konnte in Verbindung gebracht werden mit subnormalen Plasmawerten der vitamin-Kabhängigen Faktoren VII und X. 25 Patienten mussten aus der Untersuchung ausscheiden infolge von Arzneimittelinterferenzen, zusätzlichen Krankheitsgeschehen, unregelmässiger Verabreichung von Vitamin K, usw. In den übrigen 36 Fällen konnte keine der üblichen Aetiologien erworbener Hypoprothrombinämia nachgewiesen werden,-wie z.B. schlechte Darmresorption bei Mangel an Gallensalzen, Hepatopathien, Verordnung oraler Breitbandantibiotika, Arzneimittelinterferenzen, Hyperpyrexie, langfristige, exklusio parenterale Ernährung, usw. In neun Fällen (25\%) konnte mit oraler Verabreichung von Vitamin $\mathrm{K}$ eine totale, in zwei weiteren $(5,5 \%)$ eine partielle Korrektur der Faktoren VII und X erzielt werden. Die übrigen 25 Patienten $(69,5 \%)$, welche auf diese Therapie nicht ansprachen, normalisierten die betreffenden Faktoren,-mit 2 Ausnahmefällen, nach intravenöser Injektion von Vitamin K. Diese Beobachtungen unterstützen die Hypothese, wonach bie akuten Querschnittsläsionen die Darmresorption fettlöslicher Stoffe vorübergehend gestört sein kann.

\section{REFERENCES}

Bachmann, F., Duckert, F., Geiger, M., BaER, P. \& Koller, F. (1957). Differentiation of the factor VII complex. Studies on the Stuart-Prower factor. Thromb. Diath. Haemorrh. I, I69.

Berthoud, S., Bouvier, C. A. \& Krahenbuhl, B. (1966). Diagnostic différentiel d'une diathèse hémorragique aiguë: hypoprothrombinémie au cours d'une alimentation parentérale prolongée. Schweiz. Med. Wschr. 96, I522.

Butt, M. R., SNell, A. M. \& Osterberg, A. E. (1938). Use of vitamin-K and bile salts in the treatment of haemorrhagic diathesis in cases of jaundice. Proc. Mayo Clin. 13, 74 .

Cooper, I. S., Rynearson, E. H., Maccarty, C. S. \& Power, M. H. (I950). Metabolic consequences of spinal cord injury. F. Clin. Endocrin. 10, 858.

Dacie, J. V. \& Lewis, S. M. (1963). Practical Hematology, 3rd ed., p. 238. Lonson: J. A. Churchill.

Douglas, A. S. (1962). Anticoagulant Therapy. Philadelphia: F. A. Davis Comp.

Frick, P. G., RIEDleR, G. \& Brogli, H. (1967). Dose response and minimal daily requirements of vitamin-K in man. f. Appl. Physiol. 23, 387.

Lloyd, K.'E., Kaplan, L. I., Kupperman, H. S., Grynbaum, B. \& Rusk, H. A. (1964). A follow-up study of patients with spinal cord dysfunction: endocrine and metabolic findings. Arch. Phys. Med. Rehab. 45, 184.

Martius, C. (1967). Chemistry and function of vitamin-K . In Seegers, W. H., Blood Clotting Enzymology, p. 551. New York: Academic Press Inc.

Moore, M. J., Strickland, W. H. \& Prichard, R. W. (I956). Sprue with bleeding from hypoprothrombinemia. Arch. Int. Med. 97, 8I4.

O'Connell, F. B. \& Gardner, W. J. (I953). Metabolism in paraplegia. F. Amer. med. Ass. I 53, 706.

Quick, A. J. \& Collentine, G. E. (I95I). Role of vitamin-K in the synthesis of prothrombin. Amer. F. Physiol. 164, 716.

Quick, A. J. (1963). The one-stage prothrombin time determination. Its history and interpretation. Chemotherapia, 3, 313.

Quick, A. J. (I965). One-stage prothrombin time in the control of anticoagulant therapy. I2/2-K 
Anticoagulant therapy in ischemic heart disease. International Symposium I964, p. 38I (E. Sterling Nichol ed.).

RAPAPORT, S. I., AMeI, S. B., Mikkelsen, S. \& Goodman, J. R. (I960). Plasma clotting factors in hepato-cellular disease. New Engl. F. Med. 263, 278.

SATAKE, K. (1963). Blood coagulation factors in hepatic, renal and cardiovascular diseases, with special reference to the significance of the pattern on the changes of the factors. fap. F. Med. 2, 34.

WARNER, E. D., Brinkhous, K. M. \& SMITH, H. P. (1938). Bleeding tendency in obstructive jaundice: prothrombin deficiency and dietary factors. Proc. Soc. Exp. Biol. N.Y. $37,628$.

Wilson, S. J. \& DoAN, C. A. (I940). The pathogenesis of hemorrhage in artificially induced fever. Arch. Int. Med. I3, I2I4.

Zieve, P. D. \& Solomon, H. M. (I969). Variations in the response of human beings to vitamin $\mathrm{K}_{1}$. F. Lab. Clin. Med. 73, I03. 